\title{
Estimation of Heritable Relationship and Variability of Yield and Yield Determinants in Chickpea (Cicer arietinum L.)
}

\author{
Nirdesh Kumar Chaudhary ${ }^{1 *}$, Mukesh Kumar ${ }^{1}$, Pooran Chand ${ }^{1}$, S. K. Singh ${ }^{1}$, \\ Manoj Kumar Yadav ${ }^{2}$ and L. K. Gangwar ${ }^{1}$ \\ ${ }^{1}$ Department of Genetics and Plant Breeding, ${ }^{2}$ Department of Agricultural Biotechnology, \\ Sardar Vallabh Bhai Patel University of Agriculture \& Technology, \\ Meerut, Uttar Pradesh, India \\ *Corresponding author
}

\section{Keywords}

Heritable relationship, Variability, Yield, Chickpea

Article Info

Accepted:

20 May 2020 Available Online: 10 June 2020

\section{A B S T R A C T}

The present investigation was carried out with fifty one genotypes of chickpea to analyze the genetic variability, heritability, genetic advance, correlation and path analysis for ten quantitative traits. The study was carried out at Crop Research Centre (CRC) of Sardar Vallabhbhai Patel University of Agriculture and Technology, Meerut (U.P.) during Rabi season 2017-18. Material was planted in randomized block design in 3 rows plot of 4 meter length, with row to row and plant to plant spacing of $30 \mathrm{~cm}$ and $10 \mathrm{~cm}$, respectively. The observations were recorded on five randomly selected plants from each genotype in each replication for the ten characters viz,days to $50 \%$ flowering, days to maturity, plant height, number of branches per plant, number of pods per plant, number of seeds per pod, 100 seed weight, biological yield per plant, harvest index and grain yield per plant. All the 51 diverse genotypes of chickpea exhibited significant differences for all the traits under study, thus, it is implied that there was reasonably sufficient variability in the experimental material. The phenotypic coefficient of variation (PCV) and genotypic coefficient of variation (GCV) was found to be high for grain yield per plant, number of pods per plant and biological yield per plant. High heritability coupled with high genetic advance observed for grain yield per plant, number of pods per plant, biological yield per plant, 100 seed weight, harvest index, number of seeds per pod and plant height, hence direct selection of genotypes can be done through these characters for further improvement of genotypes of chickpea. In general, the genotypic correlation coefficient values were higher than the phenotypic values. This indicated that strong intrinsic associations were somewhat masked at phenotypic level due to environmental effects. Grain yield per plant had highly significant positive correlation with number of pods per plant, biological yield per plant, number of seeds per pod, harvest index, number of branches per plant and 100 seed weight at genotypic and phenotypic level. Hence, improvement of grain yield per plant can be achieved by improvement of these characters. Among the various traits studied biological yield per plant had high positive direct effect followed by harvest index at both genotypic and phenotypic levels on grain yield per plant. This indicated that biological yield per plant and harvest index are most important characters in influencing grain yield per plant. Grain yield per plant could be improved by selection based on these characters. 


\section{Introduction}

India is the world's largest producer of chickpea which shares $65 \%$ area and $61 \%$ production to the world. It is widely distributed pulse crop across the tropics, subtropics and temperate regions of the world (Rasool, 2013) with a total annual production of 14.79 million ton (Mt) from 14.56 million hectares (mha) and an average yield of 1.01 ton ha $^{-1}$. India ranks first in both area and production with 9.54 mha area followed by Australia (1.07mha), Pakistan (0.97mha), Iran (0.56mha) and 9.07 million ton production followed by Australia (2.0Mt), Myanmar (0.52Mt), Ethiopia (0.47Mt), respectively. But in productivity Israel ranks first with6130.7 $\mathrm{kg} \mathrm{ha}{ }^{-1}$ while India ranks $37^{\text {th }}$ position with $951.4 \mathrm{~kg} \mathrm{ha}^{-1}$ (FAOSTAT, 2017). Chickpeas are cultivated under both irrigated and rainfed conditions. Basically this crop is winter season crop; annually 65 to $95 \mathrm{~cm}$ rainfall is required for its cultivation. Excessive rains after sowing, flowering stage and seed maturity stage will result in heavy loss in crop yield. Desi chickpea is widely cultivated under dry lands, smaller in size, angular and having thick coats and brown to black in colour. Kabuli chickpeas are larger in size, thin coat sand range in colour from white to tan. Chickpea contains larger amount of carotenoids such as $\beta$-carotene than genetically engineered 'Golden Rice' (Abbo et al., 2005). They have unique ability of biological nitrogen fixation, deep root system; restore soil fertility, mobilization of insoluble soil nutrients and bringing qualitative enhancement in soil physical properties. To reduce the malnutrition in developing countries, seeds of chickpea offer cheapest source of protein and high nutrition (Thudi et al., 2017). It contains on an average of $4.5 \%$ fat, $8 \%$ crude fiber, $22 \%$ protein, $63 \%$ carbohydrates and $2.7 \%$ ash (Wood and Grusak, 2007) and also rich in minerals, such as calcium, magnesium, zinc, potassium, iron and phosphorus and vitamins, especially thiamine and niacin (Jukanti et al., 2012).

Improvement in yield and quality of crop is the primary objective of a plant breeder. Selection of superior plants is the basic tool of crop improvement. The efficiency of selection depends on the identification of genetic variability from the phenotypic expression of the characters. Variability means difference among the individuals of a same or different species. The variability may be due to environment or genotypes or interaction of both the components. Assessment of genetic variability in the base population is the first step in any breeding programme. The success of good breeding programme usually depends upon the genetic variability present in the breeding materials. Therefore, it is quite helpful to move on improvement in crop species through selection for different traits. The study of genetic advance is equally important as it measures the genetic gain based on selection in a particular trait.

The study of genetic variability and heritability together with genetic advance is necessary for any breeding programme through selection. The association of one or more characters influenced by a large number of genes is elaborated statistically by correlation coefficients. Genotypic correlation coefficient provides a measure of genotypes conjugation between characters.

The methods of partitioning the correlation into direct and indirect effects by path coefficients analysis was suggested by Wright (1921). It provides useful information on the relative merit of the traits in the selection criterion. Path Coefficient Analysis is a standard tool for splitting the total correlation into direct and indirect effects of yield components on yield and this is more useful in identifying suitable selection indices. 


\section{Materials and Methods}

The collections of 51genotypes of chickpea (Cicer arietinum L.) comprising indigenous, constituted the experimental materials for this study. The experiment was laid out in Randomized Block Design (RBD). Experiment was sown in three row plot of four meter length. The row to row and plant to plant distance maintain at 30 and $10 \mathrm{~cm}$ respectively. The recommended agronomical and plant protection practices were followed for the successful raising of the crop. The observations were recorded on five randomly selected and tagged plants from each entry and average values were used for the statistical analysis. The data were recorded on quantitative traits such as days to $50 \%$ flowering, days to maturity, plant height, number of branches per plant, number of pods per plant, number of seeds per pod, 100 seed weight, biological yield per plant, harvest index and grain yield per plant. The present study on chickpea was carried out to estimate the genetic variability, heritability, genetic advanced character association direct and indirect effect and genetic divergence. Analysis of variance for randomized block design (RBD) was done as per Panse and Sukhatme (1985), phenotypic co-efficient of variation and genotypic co-efficient of variation was calculated as per the formula suggested by Burton (1952) and heritability and genetic advance was estimated using the formula suggested by Allard (1960). Correlation coefficients were calculated as per the methods suggested by Searle, 1961 and path coefficient were worked out as per the method of Dewey and Lu (1959).

\section{Results and Discussion}

In the investigation, 51 diverse genotypes of chickpea were studied to assess their genetic potential. Analysis of variance revealed significant differences among the genotypes for all the characters, indicating presence of wide spectrum of variability (Table 1).Many early workers including Kuldeep et al., (2014), Mukesh Kumar et al., (2016) and Chopdar et al., (2017) reported high variability for different traits in chickpea. Thus, it is implied that there was reasonably sufficient variability in the material used for their study, which provides ample scope for selecting superior and desired genotypes by the plant breeders for further improvement.

The phenotypic and genotypic coefficient of variation (Table 2) was found to be high for grain yield per plant, number of pods per plant and biological yield per plant. Similar observations were also reported by Sharma and Saini (2010), Nizama et al., (2013) and Yadav et al., (2015). Moderate GCV and PCV (10-20) were recorded for 100 seed weight, harvest index, number of seeds per pod and plant height. These results are accordance with Nizama et al., (2013) and Ton and Anlarsal (2017). Results obtained from investigation has revealed moderate GCV and PCV indicating still there is possibility of improvement of genotypes through these characters. It is interesting to note that the differences between GCV and PCV values were minimum implying least influence of environment and additive gene effects indicating genotypes can be improved and selected for these characters.

The coefficient of variation does not offer the full scope of heritable variation. It can be determined with greater degree of accuracy when heritability in conjunction with genetic advance is studied. Hence, heritability and genetic advance are important parameters to study the scope of improvement in various characters through selection. Heritability broad sense values (Table 2) for all the characters viz., number of pods per plant, grain yield per plant, biological yield per plant, harvest index, 100 seed weight, number 
of seeds per pod, plant height and number of branches per plant was found to be high. High heritability values for these traits indicated that the variation observed was mainly under genetic control and was less influenced by environment. In confirmation with results of earlier workers viz., Nizama et al., (2013), Jivani et al., (2013), Padmavathi et al., (2013), Kuldeep et al., (2014) and Mukesh Kumar et al., (2016). Genetic advance as per cent of mean was found high (>20\%) for grain yield per plant, number of pods per plant, biological yield per plant, 100 seed weight, harvest index, number of seeds per pod and plant height. These results were confirmed by the earlier findings of as Muhammad et al., (2008), Vaghela et al., (2009), Alwawi et al., (2010) and Mukesh Kumar et al., (2016).

High heritability coupled with high genetic advance observed for grain yield per plant, number of pods per plant, biological yield per plant, 100 seed weight, harvest index, number of seeds per pod and plant height. Hence direct selection of genotypes can be done through these characters for further improvement of genotypes of chickpea. Such findings were also reported by Padmavathi et al., (2013), Kuldeep et al., (2014) and Mukesh Kumar et al., (2016). High heritability coupled with moderate genetic advance recorded for number of branches per plant suggesting further improvement of genotypes for these characters for further selection and subsequent use in breeding programme. Similar findings were obtained by Kumar et al., (2012) and Kuldeep et al., (2014). While moderate heritability coupled with low genetic advance observed for days to $50 \%$ flowering and days to maturity, rendering them unsuitable for improvement through simple selection due to prevalence of non-additive gene action. Such findings were also reported by Chopdar et al., (2017) and Mukesh Kumar et al., (2016). Correlation coefficients at genotypic and phenotypic level among the grain yield and its component characters have been worked out in study (Table 3). In general, the genotypic correlation coefficient values were higher than the phenotypic values. This indicated that strong intrinsic associations were somewhat masked at phenotypic level due to environmental effects.

The results obtained from the study revealed that grain yield per plant had highly significant positive correlation with number of pods per plant, biological yield per plant, number of seeds per pod, harvest index, number of branches per plant and 100 seed weight at genotypic and phenotypic level, such association was noticed indicating influence of environment on association. Hence, improvement of grain yield per plant can be achieved by improvement of these characters. These results were in confirmation with the report of Dehal et al., (2016), Mukesh Kumar et al., (2017), Chopdar et al., (2017), Dev et al., (2017), Samyuktha et al., (2017) and Agrawal et al., (2018). Hence, on the basis of correlation coefficient studies, it is observed, that the characters viz., number of pods per plant, biological yield per plant, number of seeds per pod, harvest index, number of branches per plant and 100 seed weight were positively correlated with grain yield per plant and also among themselves indicating their utility in selection programme for improving yield potential of population.

Path coefficient analysis (table 4) revealed that among the various traits studied, biological yield per plant had high positive direct effect followed by harvest index at both genotypic and phenotypic levels on grain yield per plant. This indicated that biological yield per plant and harvest index are most important characters in influencing grain yield per plant. Grain yield per plant could be improved by selection based on these characters. 
Table.1 Analysis of variance (ANNOVA) for ten characters in chickpea (Cicer arietinum L.)

\begin{tabular}{|c|c|c|c|c|c|c|c|c|c|c|c|}
\hline $\begin{array}{l}\text { Source of } \\
\text { Variation }\end{array}$ & d.f. & $\begin{array}{l}\text { Days to } \\
50 \% \\
\text { Flowering }\end{array}$ & $\begin{array}{l}\text { Days to } \\
\text { Maturity }\end{array}$ & $\begin{array}{l}\text { Plant } \\
\text { Height } \\
(\mathrm{cm})\end{array}$ & $\begin{array}{l}\text { No of } \\
\text { Br. } \\
\text { /plant }\end{array}$ & $\begin{array}{l}\text { No of } \\
\text { pods/plant }\end{array}$ & $\begin{array}{l}\text { No of } \\
\text { seeds/pod }\end{array}$ & $\begin{array}{l}\text { Bio- } \\
\text { yield } \\
\text { (g/plant) }\end{array}$ & $\begin{array}{l}100 \text { Seed } \\
\text { weight } \\
\text { (g) }\end{array}$ & $\begin{array}{l}\text { Harvest } \\
\text { Index } \\
(\%)\end{array}$ & $\begin{array}{l}\text { Grain Yield } \\
\text { (g/plant) }\end{array}$ \\
\hline Replication & 2 & 1.60 & 1.12 & 0.07 & 0.015 & 0.38 & 0.025 & 0.04 & 0.43 & 0.04 & 0.02 \\
\hline Treatment & 50 & $11.08 * *$ & $17.46^{* *}$ & $66.66 * *$ & $0.194 * *$ & $1765.27 * *$ & $0.090 * *$ & $358.27 * *$ & $34.21 * *$ & $127.66 * *$ & $92.95 * *$ \\
\hline Error & 100 & 1.73 & 2.78 & 0.56 & 0.002 & 1.98 & 0.001 & 0.84 & 0.21 & 0.40 & 0.12 \\
\hline
\end{tabular}

Table.2 Heritability, Genetic Advance, Genotypic and Phenotypic Coefficient of variation for ten characters in Chickpea (Cicer arietinum L.)

\begin{tabular}{|l|c|c|c|c|c|}
\hline Characters & Heritability (\%) & GA & GA as \% & $\begin{array}{c}\text { GCV } \\
(\%)\end{array}$ & PCV (\%) \\
\hline Days to 50\% Flowering & & & & & \\
\hline Days to Maturity & 64.34 & 2.92 & 3.46 & 2.10 & $\mathbf{2 . 6 1}$ \\
\hline Plant Height (cm) & 63.80 & 3.64 & 2.82 & 1.72 & $\mathbf{2 . 1 5}$ \\
\hline No of Branches /plant & 97.50 & 9.55 & 22.08 & 10.85 & $\mathbf{1 0 . 9 9}$ \\
\hline No of pods/plant & 96.50 & 0.51 & 18.08 & 8.94 & $\mathbf{9 . 1 0}$ \\
\hline No of seeds/pod & 99.66 & 49.86 & 59.13 & 28.75 & $\mathbf{2 8 . 8 0}$ \\
\hline Bio-yield (g/plant) & 97.88 & 0.35 & 24.03 & 11.79 & $\mathbf{1 1 . 9 2}$ \\
\hline 100 Seed weight (g) & 99.30 & 22.41 & 42.72 & 20.81 & $\mathbf{2 0 . 8 9}$ \\
\hline Harvest Index (\%) & 98.22 & 6.87 & 39.96 & 19.58 & $\mathbf{1 9 . 7 5}$ \\
\hline Grain Yield (g/plant) & 99.06 & 13.35 & 36.38 & 17.74 & $\mathbf{1 7 . 8 3}$ \\
\hline
\end{tabular}


Table.3 Genotypic and phenotypic correlation coefficient among ten characters in chickpea (Cicer arietinum L.)

\begin{tabular}{|c|c|c|c|c|c|c|c|c|c|c|c|}
\hline Characters & & $\begin{array}{l}\text { Days to } 50 \% \\
\text { Flowering }\end{array}$ & $\begin{array}{l}\text { Days to } \\
\text { Maturity }\end{array}$ & $\begin{array}{c}\text { Plant Height } \\
\text { (cm) }\end{array}$ & $\begin{array}{l}\text { No of Br. } \\
\text { /plant }\end{array}$ & $\begin{array}{c}\text { No of } \\
\text { pods/plant }\end{array}$ & $\begin{array}{c}\text { No of } \\
\text { seeds/pod }\end{array}$ & $\begin{array}{l}\text { Bio-yield } \\
\text { (g/plant) }\end{array}$ & $\begin{array}{l}100 \text { Seed } \\
\text { weight } \\
\text { (g) }\end{array}$ & $\begin{array}{c}\text { Harvest } \\
\text { Index }(\%)\end{array}$ & $\begin{array}{c}\text { Grain Yield } \\
\text { (g/plant) }\end{array}$ \\
\hline \multirow{2}{*}{$\begin{array}{l}\text { Days to } \\
50 \% \\
\text { Flowering }\end{array}$} & $\mathrm{G}$ & 1.000 & $0.855^{* *}$ & $0.223 * *$ & $0.311 * *$ & -0.029 & 0.146 & 0.105 & 0.090 & -0.066 & 0.010 \\
\hline & $\mathrm{P}$ & 1.000 & $0.714 * *$ & $0.171^{*}$ & $0.230 * *$ & -0.017 & 0.112 & 0.075 & 0.076 & -0.055 & 0.002 \\
\hline \multirow{2}{*}{$\begin{array}{l}\text { Days to } \\
\text { Maturity }\end{array}$} & $\mathrm{G}$ & & 1.000 & 0.129 & $0.265^{* *}$ & 0.024 & $0.160^{*}$ & $0.226^{* *}$ & 0.099 & -0.072 & 0.100 \\
\hline & $\mathrm{P}$ & & 1.000 & 0.092 & $0.208 * *$ & 0.023 & 0.117 & $0.180 *$ & 0.081 & -0.065 & 0.080 \\
\hline \multirow{2}{*}{$\begin{array}{l}\text { Plant } \\
\text { Height (cm) }\end{array}$} & G & & & 1.000 & $0.225^{* *}$ & 0.158 & 0.140 & $0.190^{*}$ & -0.010 & -0.051 & 0.075 \\
\hline & $\mathrm{P}$ & & & 1.000 & $0.203^{*}$ & 0.151 & $0.160 *$ & $0.180^{*}$ & -0.012 & -0.035 & 0.069 \\
\hline \multirow{2}{*}{$\begin{array}{l}\text { No of Br. } \\
\text { /plant }\end{array}$} & G & & & & 1.000 & $0.534^{* *}$ & $0.643 * *$ & $0.524 * *$ & $0.202^{*}$ & $0.291^{* *}$ & $0.590 * *$ \\
\hline & $\mathrm{P}$ & & & & 1.000 & $0.518^{* *}$ & $0.611^{* *}$ & $0.528^{* *}$ & $0.197 *$ & $0.275^{* *}$ & $0.590^{* *}$ \\
\hline \multirow{2}{*}{$\begin{array}{l}\text { No of } \\
\text { pods/plant }\end{array}$} & G & & & & & 1.000 & $0.592 * *$ & $0.671^{* *}$ & $0.294 * *$ & $0.575^{* *}$ & $0.875^{* *}$ \\
\hline & $\mathrm{P}$ & & & & & 1.000 & $0.581 * *$ & $0.665^{* *}$ & $0.292 * *$ & $0.569 * *$ & 0.870 ** \\
\hline \multirow{2}{*}{$\begin{array}{l}\text { No of } \\
\text { seeds/pod }\end{array}$} & G & & & & & & 1.000 & $0.630 * *$ & $0.303 * *$ & $0.382 * *$ & $0.732 * *$ \\
\hline & $\mathrm{P}$ & & & & & & 1.000 & $0.615^{* *}$ & $0.294 * *$ & $0.390 * *$ & $0.719 * *$ \\
\hline \multirow{2}{*}{$\begin{array}{l}\text { Bio-yield } \\
\text { (g/plant) }\end{array}$} & G & & & & & & & 1.000 & $0.350 * *$ & 0.020 & $0.766^{* *}$ \\
\hline & $\mathrm{P}$ & & & & & & & 1.000 & $0.346^{* *}$ & 0.016 & $0.767 * *$ \\
\hline \multirow{2}{*}{$\begin{array}{l}100 \text { Seed } \\
\text { weight }(g)\end{array}$} & G & & & & & & & & 1.000 & $0.340^{* *}$ & $0.487 * *$ \\
\hline & $\mathrm{P}$ & & & & & & & & 1.000 & $0.333 * *$ & $0.482 * *$ \\
\hline \multirow{2}{*}{$\begin{array}{l}\text { Harvest } \\
\text { Index }(\%)\end{array}$} & G & & & & & & & & & 1.000 & $0.646 * *$ \\
\hline & $\mathrm{P}$ & & & & & & & & & 1.000 & $0.638 * *$ \\
\hline \multirow{2}{*}{$\begin{array}{l}\text { Grain Yield } \\
\text { (g/plant) }\end{array}$} & $\mathrm{G}$ & & & & & & & & & & 1.000 \\
\hline & $\mathbf{P}$ & & & & & & & & & & 1.000 \\
\hline
\end{tabular}


Table.4 Genotypic and phenotypic path coefficient analysis for ten characters in chickpea (Cicer arietinum L.)

\begin{tabular}{|c|c|c|c|c|c|c|c|c|c|c|c|}
\hline Characters & & $\begin{array}{l}\text { Days to } \\
\mathbf{5 0 \%} \\
\text { Flowering }\end{array}$ & $\begin{array}{l}\text { Days to } \\
\text { Maturi } \\
\text { ty }\end{array}$ & $\begin{array}{l}\text { Plant } \\
\text { Height } \\
\text { (cm) }\end{array}$ & $\begin{array}{l}\text { No of } \\
\text { Br. } \\
\text { /plant }\end{array}$ & $\begin{array}{l}\text { No of } \\
\text { pods/pla } \\
\text { nt }\end{array}$ & $\begin{array}{l}\text { No of } \\
\text { seeds/po } \\
\text { d }\end{array}$ & $\begin{array}{l}\text { Bio- } \\
\text { yield } \\
\text { (g/plant) }\end{array}$ & $\begin{array}{l}100 \text { Seed } \\
\text { weight } \\
\text { (g) }\end{array}$ & $\begin{array}{l}\text { Harvest } \\
\text { Index }(\%)\end{array}$ & $\begin{array}{l}\text { Grain Yield } \\
\text { (g/plant) }\end{array}$ \\
\hline \multirow{2}{*}{$\begin{array}{l}\text { Days to } 50 \% \\
\text { Flowering }\end{array}$} & $\mathrm{G}$ & -0.0327 & 0.0019 & -0.0085 & 0.0089 & -0.0014 & 0.0058 & 0.0717 & 0.0023 & -0.0376 & 0.010 \\
\hline & $\mathrm{P}$ & -0.0211 & -0.0010 & -0.0088 & 0.0089 & -0.0010 & 0.0024 & 0.0517 & 0.0021 & -0.0309 & 0.002 \\
\hline \multirow{2}{*}{$\begin{array}{l}\text { Days to } \\
\text { Maturity }\end{array}$} & $\mathrm{G}$ & -0.0279 & 0.0022 & -0.0050 & 0.0075 & 0.0011 & 0.0064 & 0.1547 & 0.0025 & -0.0411 & 0.100 \\
\hline & $\mathrm{P}$ & -0.0151 & -0.0014 & -0.0048 & 0.0081 & 0.0015 & 0.0025 & 0.1232 & 0.0022 & -0.0364 & 0.080 \\
\hline \multirow{2}{*}{$\begin{array}{l}\text { Plant Height } \\
\text { (cm) }\end{array}$} & $\mathrm{G}$ & -0.0073 & 0.0003 & -0.0383 & 0.0064 & 0.0075 & 0.0056 & 0.1299 & -0.0003 & -0.0290 & 0.075 \\
\hline & $\mathrm{P}$ & -0.0036 & -0.0001 & -0.0515 & 0.0079 & 0.0094 & 0.0035 & 0.1233 & -0.0003 & -0.0197 & 0.069 \\
\hline \multirow{2}{*}{$\begin{array}{l}\text { No of Br. } \\
\text { /plant }\end{array}$} & $\mathrm{G}$ & -0.0102 & 0.0006 & -0.0086 & 0.0285 & 0.0254 & 0.0257 & 0.3583 & 0.0051 & 0.1654 & $0.590 * *$ \\
\hline & $\mathrm{P}$ & -0.0049 & -0.0003 & -0.0105 & 0.0387 & 0.0323 & 0.0133 & 0.3616 & 0.0054 & 0.1543 & $0.590 * *$ \\
\hline \multirow{2}{*}{$\begin{array}{l}\text { No of } \\
\text { pods/plant }\end{array}$} & $\mathrm{G}$ & 0.0010 & 0.0001 & -0.0061 & 0.0152 & 0.0476 & 0.0236 & 0.4591 & 0.0075 & 0.3268 & $0.875 * *$ \\
\hline & $\mathrm{P}$ & 0.0004 & 0.0000 & -0.0078 & 0.0201 & 0.0623 & 0.0126 & 0.4554 & 0.0081 & 0.3188 & $0.870 * *$ \\
\hline \multirow{2}{*}{$\begin{array}{l}\text { No of } \\
\text { seeds/pod }\end{array}$} & G & -0.0048 & 0.0004 & -0.0054 & 0.0183 & 0.0282 & 0.0399 & 0.4308 & 0.0077 & 0.2174 & $0.732 * *$ \\
\hline & $\mathrm{P}$ & -0.0024 & -0.0002 & -0.0082 & 0.0237 & 0.0362 & 0.0218 & 0.4208 & 0.0081 & 0.2188 & $0.719 * *$ \\
\hline \multirow{2}{*}{$\begin{array}{l}\text { Bio-yield } \\
\text { (g/plant) }\end{array}$} & $\mathrm{G}$ & -0.0034 & 0.0005 & -0.0073 & 0.0149 & 0.0319 & 0.0251 & 0.6843 & 0.0089 & 0.0114 & $0.766 * *$ \\
\hline & $\mathrm{P}$ & -0.0016 & -0.0003 & -0.0093 & 0.0204 & 0.0414 & 0.0134 & 0.6848 & 0.0095 & 0.0089 & $0.767 * *$ \\
\hline \multirow{2}{*}{$\begin{array}{l}100 \text { Seed } \\
\text { weight }(g)\end{array}$} & $\mathrm{G}$ & -0.0029 & 0.0002 & 0.0004 & 0.0058 & 0.0140 & 0.0121 & 0.2395 & 0.0254 & 0.1929 & $0.487 * *$ \\
\hline & $\mathrm{P}$ & -0.0016 & -0.0001 & 0.0006 & 0.0076 & 0.0182 & 0.0064 & 0.2368 & 0.0276 & 0.1866 & $0.482 * *$ \\
\hline \multirow{2}{*}{$\begin{array}{l}\text { Harvest } \\
\text { Index }(\%)\end{array}$} & $\mathrm{G}$ & 0.0022 & -0.0002 & 0.0020 & 0.0083 & 0.0274 & 0.0153 & 0.0138 & 0.0086 & 0.5683 & $0.646^{* *}$ \\
\hline & $\mathbf{P}$ & 0.0012 & 0.0001 & 0.0018 & 0.0107 & 0.0354 & 0.0085 & 0.0108 & 0.0092 & 0.5604 & $0.638 * *$ \\
\hline
\end{tabular}

Residual effect $=0.0118$ and 0.0147 
The direct effects of remaining characters on grain yield per plant were of low magnitude. These results are in general agreement with the finding of Jadhav et al., (2014), Dehal et al., (2016), Mukesh Kumar et al., (2017), Chopdar et al., (2017), Dev et al., (2017) and Agrawal et al., (2018). Biological yield per plant showed positive high indirect effect on grain yield per plant via, number of pods per plant, number of seeds per pod and number of branches per plant at both genotypic and phenotypic level. Harvest index exhibited high positive indirect contribution on grain yield per plant via, number of pods per plant, number of seeds per pod and 100 seed weight. Similar result was also supported by the findings of Mukesh Kumar et al., (2016) and Chopdar et al., (2017). Path analysis identified, biological yield per plant and harvest index as important direct yield contributing characters, which were also found to be useful indirect contributors via each other. Biological yield per plant and harvest index emerged as most important indirect yield components. The characters mentioned above, merit due consideration at the time of devising selection strategy aimed at developing high yielding varieties in chickpea.

The contribution of residual effects that influenced grain yield per plant was very low at both genotypic and phenotypic levels indicating that the characters included in the present investigation were sufficient enough to account for the variability in the dependent character i.e. grain yield per plant.

\section{References}

Abbo, S., Molina, C., Jungmann, R., Grusak, M.A., Berkovitch, Z., Reifen, R., Kahl, G., Winter, P., Reifen, R. 2005. Quantitative trait loci governing carotenoid concentration and weight in seed of chickpea (Cicer aritenium L.). Theor. Appl. Genet.111:185-195.
Agrawal, T., Kumar, A., Kumar, S., Kumar, A., Kumar, S., Kumar R.R and Singh P.K. 2018. Correlation and Path Coefficient Analysis for Grain Yield and Yield Components in Chickpea (Cicer arietinum L.) under Normal and Late Sown Conditions of Bihar, India. Int.J.Curr.Microbiol.App.Sci 7(2): 16331642.

Allard, R.W. 1960. Principles of Plant Breeding. John Wiley and Sons Inc. New York.

Alwawi, H., Moulla, M. and Choumane, W. 2010. Genotype - environment interaction and genetic parameters in chickpea landraces. $J$. Agri. Sci., 1(2): 154-161.

Burton, G W. 1952. Quantitative inhentence in grasses Proceedings of the sixth International Grass land congress Vol 1 277-283

Chopdar, D.K., Baudh, B., Sharma, P.P., Dubey, R.B., Brajendra and Meena, B.L. 2017. Studies on genetic variability, character association and path analysis for yield and its contributing traits in chickpea (Cicer arietinum L.). Legume Research 40:824829

Dehal, I.B.,Kalia, R. and Kumar, B. 2016. Genetic estimates and path coefficient analysis in chickpea (Cicer arietinum L.) under normal and late sown environments. Legume Research, 39(4): 510-516.

Dev, A., Verma, P. and Kumhar B.L. 2017. Genetic character variability studies in desi chickpea (Cicer arietinum L.) genotypes. Int. J. Curr. Microbiol. App. Sci., 6(4): 2025.

Dewey, D.R. and Lu, K.H. (1959). A correlation and path coefficient analysis of components of crested wheat grains seed production. Agron. J., 51: 515-518.

FAO, 2017. FAOSTAT. Food and Agriculture Organization of the United Nations. http://faostat.fao.org/default.aspx.

Jivani, J.V., Mehta, D.R., Vaddoria, M. and Raval, Lata. 2013. Correlation and path coefficient analysis in chickpea. Electronic J. Pl. Breed., 4(2): 1167-1170.

Jukanti, A.K., Gaur, P.M., Gowda, C.L.L. and Chibbar, R.N., 2012. Nutritional quality and health benefits of chickpea (Cicer arietinum L.). British Journal of Nutrition, 
108: S11-S26.

Kuldeep, R.K., Pandey, S. Babbar, A. and Mishra, D.K. 2014. Genetic variability, character association and path coefficient analysis in chickpea grown under heat stress conditions .Electronic J. Plant Breeding, 5(4): 812819.

Kumar, Abhishek; Babu, G. Suresh; Lavanya, G. Roopa 2012. Character association and path analysis in early segregating population in chickpea. Legume research; 35(4): 337-340

Muhammad, A.A., Nawab, N.N. Ghulam, R. and Muhammad, S. 2008. Estimates of variability and correlations for quantitative traits in chickpea. J. Agri. Soc. Sci., 4: 17779.

Mukesh Kumar, Piyush Malik, Vipin Kumar, Arvind Kumar and Rajendra Singh2016 .Estimation of genetic variability, heritability and genetic advance for Yield and its characters in chickpea (Cicer arietinum L.). Progressive Research Vol. 11(3): 570-572.

Mukesh Kumar, Piyush Malik, Vipin Kumar, Arvind Kumar and S.K. Tirpathi 2017. Determination of selection criteria with correlation and path coefficient analysis in chickpea (Cicer arietinum L.). Progressive Agriculture Vol. 17(1): 168-172.

Nizama, J.R. 2013. Genetic variability and heritability among quantitative traits in chickpea under tropical region. Asian Resonance, 2(4): 45-48.

Padmavathi, P.V., Murthy, S.S., Rao, V.S. and Ahamed, M.L. 2013. Correlation and path coefficient analysis in kabuli chickpea (Cicer arietinum L.). Int. J. Appl Biol Pharma. Tech.4 (3): 107-110

Panse, V.G. and Sukhatme, P.V. 1969. Statistical methods for agricultural workers. Indian Council of Agricultural Research, New
Delhi.

Rasool, S., 2013. Genetic diversity as revealed by RAPD analysis among chickpea genotypes. Pakistan Journal of Botany, 45(3): 829834.

Searle, S.R. 1961. Phenotypic, Genotypic and environmental correlations. Biometrics, 47: 474-480.

Sharma, L.K. and Saini, D.P. 2010. Variability and association studies for seed yield and yield components in chickpea. Res. J. Agri. Sci., 1(3): 209-211.

Thudi, K., Roorkiwal, M., Kudapa, H., Chaturvedi, S.K., Singh, N.P. and Varshey, R.K. 2017. An overview of chickpea research: from discovery to delivery. Pulse India, 2(5): 22-25.

Ton, A. and Anlarsal, A.E. 2017. Estimation of genetic variability for seed yield and its components in chickpea (Cicer arietinum L.) genotypes. Legume Research 40:11331135

Vaghela, M.D., Poshiya, V.K., Savaliya, J.J. and Mungra, K.D. 2009. Studies on character association and path analysis for seed yield and its components in chickpea (Cicer arietinum L.). Legumes Research, 32: 245249.

Wood, J.A. and Grusak, M.A., 2007.Nutritional value of chickpea in Chickpea breeding and management. $C A B$ International, UK, 101142 .

Wright, S. 1921. Correlation and causation. J. Agric. Res. 20: 557-587.

Yadav, P. Tripathi, D.K. Khan, K.K. and Yadav, A.K. 2015. Determination of genetic variation and heritability estimates for morphological and yield traits in chickpea (Cicer arietinum L.) under late sown conditions. Indian J. Agric. Sciences, 85(7): 877-82.

\section{How to cite this article:}

Nirdesh Kumar Chaudhary, Mukesh Kumar, Pooran Chand, S. K. Singh, Manoj Kumar Yadav and Gangwar, L. K. 2020. Estimation of Heritable Relationship and Variability of Yield and Yield Determinants in Chickpea (Cicer arietinum L.). Int.J.Curr.Microbiol.App.Sci. 9(06): 2511-2519. doi: https://doi.org/10.20546/ijcmas.2020.906.305 